\title{
Is sustainability certification for biochar the answer to environmental risks?
}

\author{
Annette L. Cowie(1), Adriana E. Downie ${ }^{(2)}$, Brendan H. George ${ }^{(3)}$, Bhupinder-Pal Singh ${ }^{(4)}$, \\ Lukas Van Zwieten ${ }^{(5)}$ and Deborah O'Connell(6)
}

\begin{abstract}
(1)University of New England (UNE), Rural Climate Solutions/New South Wales Department of Primary Industries (NSW DPI), UNE Armidale, NSW 2351 Australia. E-mail: annette.cowie@une.edu.au (2)Pacific Pyrolysis Pty. Ltd., 56 Gindurra Road, Somersby, NSW 2250 Australia. E-mail: adriana.downie@pacificpyrolysis.com (3)UNE/NSW DPI, Rural Climate Solutions, 4 Marsden Park Rd., Tamworth, NSW 2340 Australia. E-mail: brendan.george@dpi.nsw.gov.au ${ }^{(4)}$ NSW DPI, PO Box 100, Beecroft, NSW 2119 Australia. E-mail: bp.singh@sf.nsw.gov.au (5) UNE/NSW DPI, Rural Climate Solutions, 1243 Bruxner Highway, Wollongbar. NSW 2477 Australia. E-mail: lukas.van.zwieten@dpi.nsw.gov.au ${ }^{(6)}$ Commonwealth Scientific and Industrial Research Organisation Ecosystem Sciences, GPO Box 1700, Canberra, ACT 2601 Australia. E-mail: Deborah.O'Connell@csiro.au
\end{abstract}

\begin{abstract}
Biochar has the potential to make a major contribution to the mitigation of climate change, and enhancement of plant production. However, in order for biochar to fulfill this promise, the industry and regulating bodies must take steps to manage potential environmental threats and address negative perceptions. The potential threats to the sustainability of biochar systems, at each stage of the biochar life cycle, were reviewed. We propose that a sustainability framework for biochar could be adapted from existing frameworks developed for bioenergy. Sustainable land use policies, combined with effective regulation of biochar production facilities and incentives for efficient utilization of energy, and improved knowledge of biochar impacts on ecosystem health and productivity could provide a strong framework for the development of a robust sustainable biochar industry. Sustainability certification could be introduced to provide confidence to consumers that sustainable practices have been employed along the production chain, particularly where biochar is traded internationally.
\end{abstract}

Index terms: climate change, life cycle assessment, risk management, sustainable land management.

\section{A certificação de sustentabilidade do "biochar" é a resposta para os riscos ambientais?}

Resumo - O "biochar" tem potencial para dar uma importante contribuição para a mitigação das mudanças climáticas e para o aumento da produção vegetal. No entanto, para que o "biochar" possa atender a esta expectativa, a indústria e os organismos reguladores devem seguir alguns passos para gerenciar as potenciais ameaças ambientais e abordar as percepções negativas. As ameaças potenciais à sustentabilidade dos sistemas de "biochar", para cada estágio de seu ciclo de vida foram revisadas. Nós propomos que a estrutura da sustentabilidade para o "biochar" poderia ser adaptada de estruturas já existentes, desenvolvidas para a bioenergia. Políticas de uso sustentável da terra, combinadas com a regulação efetiva das instalações de produção do "biochar" e incentivos para a utilização eficiente de energia, além do conhecimento aperfeiçoado dos impactos do "biochar" na saúde e na produtividade do ecossistema, poderiam fornecer uma estrutura robusta para o desenvolvimento de uma indústria sustentável de "biochar". A certificação de sustentabilidade poderia ser introduzida, para proporcionar confiança aos consumidores de que práticas sustentáveis foram empregadas ao longo da cadeia de produção, particularmente onde o "biochar" é comercializado internacionalmente.

Termos para indexação: mudanças climáticas, avaliação do ciclo de vida, gerenciamento de risco, gerenciamento sustentável da terra.

\section{Introduction}

Biochar has the potential to make a major contribution towards mitigating climate change and enhancing agricultural productivity (Lehmann et al., 2006). However, in order for this potential to be realized, the adoption of biochar must occur together with implementation of adequate controls to manage potential environmental threats associated with its deployment. The overall sustainability of biochar production and use, including sourcing of the feedstock, manufacture, and application, needs to be considered to ensure that there is a net positive impact when environmental, social, and economic perspectives are considered.

The global technical potential for mitigation of greenhouse gas (GHG) emissions through biochar 
made from sustainably produced biomass sources has been estimated at $6.6 \mathrm{Gt} \mathrm{CO}_{2}$-equivalent $\left(\mathrm{CO}_{2}\right.$-e $)$ annually (Woolf et al., 2010). Although both positive and negative impacts on crop productivity have been recorded, a meta-analysis of published responses to biochar application showed that, on average, yields were increased by $10 \%$ (Jeffery et al., 2011), while some studies have found stimulation of plant growth by up to $100 \%$ or more (Peng et al., 2011; Waters et al., 2011). Significant opportunities also exist for biochar to be used for environmental remediation, such as for enhancing biodegradation of petroleum hydrocarbons in soil (Bushnaf et al., 2011), immobilizing and thereby reducing the bioavailability and phytotoxicity of heavy metals (Namgay et al., 2010; Park et al., 2011), adsorbing polycyclic aromatic hydrocarbon (PAH) in soils (Chen \& Yuan, 2011), and preventing herbicide leaching and subsequent contamination of water bodies (Sun et al., 2011). Therefore, biochar may deliver sustainability benefits beyond GHG emission abatement, through enhanced food production and land remediation.

Despite many reports of positive plant growth responses, and demonstration of potential climate change mitigation benefits (Gaunt \& Cowie, 2009; Roberts et al., 2010; Woolf et al., 2010), the promise of biochar has not been embraced universally. Potential risks to the sustainability of biochar systems have been identified by a number of stakeholders (Biofuelwatch, 2011; Downie et al., 2012). Management options have been proposed, and some implemented, to mitigate these risks, to ensure that a net positive outcome is achieved (Downie et al., 2012). Sustainability certification, such as has been implemented in the forestry industry (Karmann \& Smith, 2009), may offer a mechanism to improve confidence of consumers and regulators in the sustainability of biochar.

In this paper, we take a life cycle perspective to assess the aspects of biochar production and use that may contribute, either positively or negatively, to the overall sustainability of the biochar concept. We propose that certification can play a role in promoting sustainable practices in biochar production and use. Economic options and impacts of establishing and employing biochar systems were not considered.

\section{Sustainability of Biochar Systems}

\section{Feedstock acquisition}

The source of biomass used for biochar production is a key aspect in the overall sustainability of the system. Biomass is a renewable but finite resource that often has many competing uses, and delivers a range of economic, social, and environmental services.

Biomass for biochar may be sourced from residues that would otherwise be sent to landfill or incinerated. In such cases, the use of biochar may avoid release of the powerful GHG methane and nitrous oxide, minimize nutrient contamination of groundwater, enhance resource recovery, and reduce the volume of material being sent to landfill, thus delivering multiple environmental benefits. Several investigations into the potential of biochar systems have targeted low-value biomass resources that are underutilized and will be replenished within the timeframes required for continuous supply (Woolf et al., 2010; Duku et al., 2011).

Sourcing biomass from an established alternative use requires scrutiny to ensure that negative impacts are minimized. For example, if biomass is obtained from crop stubbles, dedicated biomass crops or plantation forest harvest residues, there is a risk that their removal will lead to decline in soil fertility, reduction in soil carbon stocks, and increased erosion (Cowie et al., 2006; Janowiak \& Webster, 2010; Farine et al., 2011; Werhahn-Mees et al., 2011). Alternatively, if biomass is obtained from native forests, harvesting of this resource must be managed to reduce risk of loss of carbon stock in biomass and soil, and to reduce potential threats to environmental services (water quality, biodiversity conservation) (Biofuelwatch, 2011). Sustainable land management practices that minimize nutrient removal and erosion can reduce these risks (Cowie et al., 2006). The risk that purpose-grown crops or plantations may displace other land uses leading to deforestation elsewhere ("indirect land use change") should also be considered.

Understanding the risks and developing appropriate management systems for the acquisition of biomass feedstocks for biochar is important to ensure that sustainable systems are deployed.

\section{Biochar production}

Biochar is manufactured by heating biomass in oxygen-limitedconditions. Traditionalcharcoal-making 
processes may utilize pits, mounds or simple kilns, while advanced pyrolysis technologies involve continuous rather than batch processes, operated in complex engineered plants where process conditions are well-controlled (Brown, 2009). Sustainability concerns in the manufacture of biochar include the potential release of air pollutants, emissions of GHG, and conversion efficiency of biomass resources to biochar and energy products.

Biochar production through traditional charcoal-making processes commonly releases particulates and methane. The former may affect human health, while the latter is a powerful GHG, with global warming potential 25 times higher than $\mathrm{CO}_{2}$ (Forster et al., 2007). Both of these issues are managed in modern production facilities through capture and use of volatiles in powering the process, and the use of modern emission-control methods. As a minimum, volatiles should be flared to convert methane to the less-powerful $\mathrm{GHG} \mathrm{CO}_{2}$.

Where feedstock materials are derived from waste streams, risk of harmful emissions is increased, due to the presence of contaminants. For example, municipal wastes are likely to contain glass, hard plastic, film plastic, metals and textile contamination (Brinton Junior, 2005). Compost standards regulate for these contaminants (Standards Australia, 2003), and it will be important to introduce similar regulation for biochar products. A contaminant of particular concern is polyvinyl chloride (PVC), found in products such as pipes, sheets, panels, tiles, toys, adhesives, and paints, which may lead to dioxin formation during thermal treatment, potentially resulting in air quality issues. Chlorinated PVC (CPVC), in particular, is a risk as it has been shown to release hydrogen chloride and form chlorinated aromatic rings (Urabe \& Imasaka, 2000). However, under pyrolysis conditions, where oxygen is restricted during thermal processing, the formation of dioxins can be minimized or avoided (Wijesekara et al., 2011), so the risk of dioxin formation from PVC is lower using pyrolysis, compared to other technologies such as gasification or incineration.

Metals that would be expected to sublimate (e.g., mercury, cadmium and, to a lesser extent, arsenic) could contaminate local environments surrounding the processing facility, and may also cause risks to operators. One of the greatest risks for air quality is feedstock contaminated with treated wood. Common treatments of concern include chromated copper arsenate (CCA), high-temperature creosote (HTC), pigmented emulsified creosote (PEC), and light organic solvent preservative (LOSP). Waste wood sources may also contain painted surfaces, with older paints likely to contain lead compounds. Laboratory scale pyrolysis of CCA treated wood has shown that increasing temperature results in a slight increase in arsenic volatilization up to $390^{\circ} \mathrm{C}$, with a sharp increase in volatilization at higher temperatures. Chromium loss was less affected by increasing temperature (Cuypers \& Helsen, 2011). In a separate study by Kakitani et al. (2004), pyrolysis of CCA-treated wood showed that the arsenic was initially decomposed to arsenic pentoxide, which then appeared to be released at around $400-500^{\circ} \mathrm{C}$ as arsenic trioxide, and to a lesser extent, an unreacted arsenic compound. Pyrolysis temperatures around $300-350^{\circ} \mathrm{C}$ resulted in almost all toxic elements remaining in the biochar.

Dioxin, heavy metal and particulate emissions are commonly regulated in air-quality standards. Concerns remain for non-engineered systems that pyrolyze biomass without an appropriate gas emission clean up mechanism, such as those operating in countries with limited enforcement of environmental regulations, or at a small scale where such regulations may not apply.

The net GHG mitigation across the biochar lifecycle will be contingent on the energy efficiency of the conversion process. The use of fossil fuels in biochar manufacture will undermine the saving in emissions through delayed degradation of biomass. Therefore, processing plants that have higher levels of energy efficiency, such as through the utilization of the synthesis gas (syngas) produced during pyrolysis for internal heating requirements and bioenergy export to offset fossil fuel used in harvesting and pre-processing, will be more sustainable than more simple processes that do not utilize the syngas.

Environmental impacts at a processing plant are generally more tractable to manage than many of the other impacts along the value chain. Therefore, identification of impacts can be directly linked to mitigation strategies to manage the risk, and thus, the sustainability outcomes for this part of the value chain are potentially readily attainable.

\section{Biochar utilization}

The sustainability issues of relevance to the utilization stage of the biochar life cycle relate to its 
impacts and interactions when applied to soil. These can include (Verheijen et al., 2010): impacts on the carbon cycle - stabilization of $\mathrm{C}$ in biochar and stimulation or inhibition of soil organic matter decomposition; physical impacts on soil structure, water holding capacity, and hydrophobicity; biological and chemical impacts on soil biota, nutrient cycling, and nutrient balances; and impacts from possible contaminants in biochar.

Specific issues for sustainability are considered further below.

Biochar has been increasingly recognized as a recalcitrant material that can provide long-term carbon sequestration in soil (Lehmann \& Joseph, 2009; Singh $\&$ Cowie, 2010). However, concerns have been raised about its potential to stimulate decomposition of native soil organic matter, known as a "positive priming" effect, which could potentially offset carbon gains from biochar application. For example, forest-derived charcoal has been shown to stimulate loss of boreal forest humus by increasing microbial activity in the associated charcoal-humus mixtures contained within litterbags (Wardle et al., 2008). More recently, Luo et al. (2011) reported enhanced mineralization of native soil organic carbon in the presence of biochar, apparently stimulated by water-soluble components of biochars. Cross \& Sohi (2011) showed that although labile biochar-derived carbon was the major source of enhanced short-term carbon loss from biochar-amended soils, biochar presence has the potential to reduce native organic loss from agricultural soils. Similarly, Keith et al. (2011) showed that biochar application reduced the mineralization of added sugarcane residues in a smectitic clay soil, which they attributed to possible sorption of labile organic matter on biochar and to interactions between biochar, native organic matter and soil minerals stimulated by the addition of labile organic matter (sugarcane residue). Likewise, Liang et al. (2010) observed rapid stabilization of added labile organic matter (sugarcane residues) into organo-mineral fractions in 'aged' biochar-amended Anthrosols. The balance of evidence suggests that the application of biochar may stimulate native soil organic matter decomposition in the short term, but the magnitude of organic carbon loss is generally small and unlikely to significantly reduce the large carbon sequestration potential of biochar (Cross \& Sohi, 2011; Keith et al., 2011; Luo et al., 2011). Further research is needed, using biochars with different mineralization rates and soluble organic matter contents to examine the timing, direction and persistence of the priming effect of biochar in soils of contrasting mineralogy and carbon levels.

Several studies have found an increase in the water-holding capacity of different soils with increasing rate of biochar (Fellet et al., 2011; Karhu et al., 2011; Streubel et al., 2011). Biochar also enhances aggregation (Fellet et al., 2011), so it may improve infiltration of rainfall. Thus, biochar may increase tolerance of agricultural systems to drought (Kammann et al., 2011). However, biochars may increase hydrophobicity, due to alkyl functional groups, although, increases in field-capacity water content, and negligible impacts on hydrophobicity are observed when biochars are produced at temperatures between 400 and $600^{\circ} \mathrm{C}$ (Kinney et al., 2012).

Biochar has reactive surfaces that can adsorb nutrients, reducing leaching (Singh et al., 2010) and, thus, contributing to reduced environmental contamination and increased fertilizer use efficiency (Van Zwieten et al., 2010a). The sorptive capacity of biochar can also produce negative effects; Kookana et al. (2011) observed that biochar reduced the efficacy of pre-emergent herbicides, while also reducing their biodegradability, which suggests that greater rates of herbicides may be required where biochar is applied, and that these chemical will be more persistent in the environment.

Concerns have been raised about whether biochars contain dioxins or $\mathrm{PAH}$, leading to environmental contamination. However, studies have found very low levels of dioxin, and generally low levels of PAH in a wide range of biochars (Downie et al., 2012). Concerns have also been expressed about whether biochar produced from contaminated feedstocks may contain toxic components, which could contaminate agricultural lands (Verheijen et al., 2010). Biochars with elevated metal concentrations can occur from feedstocks such as biosolids and animal manures (Van Zwieten et al., 2010b). Metals and minerals in the feedstock that have sublimation temperatures above the temperature of the pyrolysis reactor will concentrate into the biochar (Bridle \& Pritchard, 2004), with concentration factors dependent upon the mass loss of biomass during the pyrolysis process. Controls are required to ensure that biochar applied to soil does 
not exceed acceptable thresholds for heavy metals and other possible contaminants. Biochar application to contaminated soils can, in fact, reduce the availability of some heavy metals (Namgay et al., 2010; Uchimiya et al., 2012) and PAH (Gomez-Eyles et al., 2011).

Several authors have stressed the need for better understanding of long-term agronomic and environmental impacts of biochar application to soils (Verheijen et al., 2010; Kookana et al., 2011). Nevertheless, the need for additional research should not delay the deployment of biochar in situations where benefits have been shown and risks are minimal. Guidelines can be devised to identify these low-risk situations.

\section{GHG impacts across the biochar life cycle}

Life cycle assessment (LCA) is a tool devised to quantify the total environmental impact of a product or process (International Organization for Standardization, 2006). LCA has been widely employed to assess the climate change impacts of bioenergy systems (Cherubini et al., 2009; Cherubini, 2010). Several studies employing LCA or partial LCA approaches have been used to quantify the climate change impacts of biochar production and use (Gaunt \& Cowie, 2009; Roberts et al., 2010; Woolf et al., 2010; Hammond et al., 2011). LCA assesses the GHG emissions and sequestration across the biochar life cycle including aspects highlighted in the previous sections - such as changes in soil and biomass carbon stocks due to procurement of biomass; fossil fuel use in harvesting, processing, transport and application of biochar; and indirect emissions such as from fertilizer manufacture. Emissions of all relevant GHG are included, that is, $\mathrm{N}_{2} \mathrm{O}$ and $\mathrm{CH}_{4}$ as well as $\mathrm{CO}_{2}$. The net impact of biochar is determined by comparing the biochar life cycle with the applicable reference system, representing the conventional soil amendment and use of the biomass, and, where the biochar production process produces an energy co-product, the conventional energy source.

LCA studies have estimated net emissions reduction for different biochar scenarios at $0.7-3.1 \mathrm{Mg} \mathrm{CO}_{2}$-e per $\mathrm{Mg}$ (dry) feedstock, if indirect land use change is omitted (Gaunt \& Cowie, 2009; Roberts et al., 2010; Hammond et al., 2011). However, where purpose-grown biomass is used for biochar, and indirect land use change is assumed to occur, the benefits are reduced, and emissions could even be increased (Roberts et al., 2010). The wide variation in these assessments results from differences in the biochar scenarios (feedstock, design and scale of pyrolysis plant, displaced fossil energy source) and differences in assumed impacts of biochar. Uncertainty is high, particularly for the impacts of biochar on plant growth, fertilizer requirements and nitrous oxide emissions.

Biochars from wood residues have a greater emission mitigation potential than biochars from manures, because manure biochars have a shorter mean residence time in soil than that of wood biochars (Singh \& Cowie, 2010). In general, there is greater benefit from biochar made from residues than from purpose-grown biomass crops, due to additional fossil fuel inputs and losses of soil carbon in producing the biomass, and due to the decomposition emissions assumed to be avoided where residues are used (Roberts et al., 2010).

Temperature of the pyrolysis kiln affects the stability of the biochar and the yield of biochar vs syngas: at higher temperatures, the biochar produced is more resistant to decay in soil (Singh \& Cowie, 2010), but there is less biochar produced. Beneficial use of syngas released during the pyrolysis process to displace fossil energy is an important contributor to the abatement value of biochar systems. Displacement of GHG-intensive energy sources such as electricity from brown coal, gives greater abatement than displacement of less GHG-intensive sources such as electricity from natural gas (Cherubini et al., 2009).

Reduction in nitrous oxide emissions from agricultural soils is an important contributor to abatement, so assumed benefits are greater for crops with high nitrous oxide emissions, such as irrigated crops with high-nitrogen fertilizer requirements.

The major contribution to abatement arises from carbon storage in the biochar (Roberts et al., 2010; Hammond et al., 2011). The contributions of organic matter stabilization, avoided nitrous oxide emissions from soil, avoided methane emissions from landfill, and displacement of fossil fuel emissions vary between alternative scenarios, and are highly dependent on the assumptions employed (Wu et al., 2008; Gaunt \& Cowie, 2009; Roberts et al., 2010; Hammond et al., 2011). The total abatement value can be greater than the $\mathrm{CO}_{2}$ sequestered in biomass, and can be greater than if the biomass was used solely for bioenergy (Woolf et al., 2010; Hammond et al., 2011).

There is potential for biochar systems to generate carbon credits in emissions trading markets and, thus, 
provide a financial incentive for the adoption of biochar technologies (Gaunt \& Cowie, 2009). Acceptance of biochar in emissions trading schemes will require confidence in the calculation and verification of the abatement claimed. Sustainability certification, discussed below, could contribute to confidence in biochar as a legitimate offset.

\section{Managing risks}

\section{Filling the knowledge gaps}

We know that some biochars are more effective in mitigating $\mathrm{GHG}$ emissions and improving productivity than others, and that some crops and some soils are more responsive than others (Waters et al., 2011). We also know that biochar can sometimes have negative agronomic impacts (Jeffery et al., 2011), and that its properties are dependent on the biomass feedstock and the production process (Singh et al., 2010). Nevertheless, research into biochar properties and the interactions of biochar with soil, plants and microorganisms is still in its infancy and is likely to expand over the coming years. Current research aims to develop methods for characterizing key properties of biochar, to enable the matching of particular biochars to crop requirements and soil limitations (Cross \& Sohi, 2011). As knowledge grows, the targeted application of biochar to environmentally beneficial applications will become more prescriptive, and uncertainty in calculation of GHG impacts will be reduced.

Future research should aim to understand the overall capability and limitations of the various biochar systems that may develop utilizing different biomass sources and process technologies, and targeting different biochar markets. This research should focus on elucidating underlying processes. A comprehensive understanding of all aspects of every biochar in every soil system will be expensive and time-consuming to achieve; rather than waiting for such research, process-level knowledge should be used to define sustainable applications and develop good practice guidelines, to minimize risks. This will allow roll-out of biochar systems to commence, and climate change mitigation benefits to accrue.

\section{Sustainability assessment}

The rapid expansion of the bioenergy industry (and in particular the so-called 'first generation' biofuels) through the early 2000's led to many sustainability issues arising, through both direct and indirect effects (Delucchi, 2010). Many governments and market segments now consider that quantitative, robust and independently verified sustainability credentials are vital in order for the bioenergy industry to expand globally (O'Connell et al., 2009). This recognition is translating into government policies in many countries, which will confine market access and government support to those bioenergy products (i.e., biomass, or energy carriers such as biofuel) which meet specified sustainability criteria or standards. In response to this, there is a proliferation of approaches including policy and regulatory instruments. As well, voluntary compliance mechanisms, such as certification and industry codes of conduct, are being developed for domestic and international markets. Lewandowski \& Faaij (2006), Fehrenbach et al. (2008), Van Dam et al. (2008) and O'Connell et al. (2009) have reviewed the principles, objectives, criteria and indicators used to assess sustainability across a range of certification and reporting systems of relevance to biomass. Table 1 lists some of the major schemes. We assert that the schemes being developed for the bioenergy industry are directly relevant, and could be applied to the feedstock sourcing and plant operation stages of biochar systems.

\section{Towards a sustainability framework for biochar}

Amongst the plethora of established and developing bioenergy sustainability assessment initiatives, listed in Table 1 are the schemes we consider to hold the greatest relevance for adaptation to biochar systems. Sustainability criteria and indicators developed for biochar will need to extend beyond the existing bioenergy sustainability schemes, to encompass the effects on soil, any substitution of soil amendments, as well as the sequestration value of the biochar. The adaptation and ongoing development of any sustainability scheme for biochar should aim to harmonize with other schemes and approaches, for consistency, to minimize duplication, and to reduce the burden on producers seeking to assess biochar sustainability.

A scientifically robust and socially accepted sustainability framework for biochar should be developed utilizing knowledge of biochar impacts and mitigation value. Devising such a framework requires, a scientifically-based conceptual framework for sustainability assessment; engagement of a broad 
range of stakeholders, working to achieve consensus; and institutional mechanisms involving regulation and incentives, at domestic and international level, to ensure the widespread adoption of agreed sustainability assessment and assurance measures (O'Connell et al., 2009).

A framework for sustainable biochar production and use should comprise agreed sustainability principles, encompassing: environmental, social and economic goals; articulated criteria that describe the elements of sustainability; and specific indicators for monitoring and assessment of trends in sustainability (O'Connell et al., 2009). Indicators need to be practical, cost-effective, outcome-based, and sensitive to change in significant processes of the human-environment system. They should be relevant across a range of locations and production systems, and have minimal transaction costs, to encourage industry participation, while maintaining sufficient rigor to ensure credibility. Ensuring that small-scale producers are covered, but not disadvantaged, will be a significant challenge.

Sustainability must be clearly defined, then assessed and assured at each stage of the value chain, and for the system as a whole. The following elements should be considered in determining and assessing the sustainability of biochar systems: 1, environmental impacts of biomass procurement on soil health (including nutrient levels, organic matter, structural stability, and erosion), on water resources, and on biodiversity - considering both on-farm impacts and offsite impacts including indirect land use change; 2 , impacts of biochar production (e.g. GHG emissions and release of pollutants, efficiency of utilization of syngas, and process heat to displace fossil energy sources); 3 , impacts of biochar application (e.g. on soil health, nutrient leaching, and efficacy of pesticides); 4, local and regional social impacts (e.g. impacts on rural incomes and health); and 5, whole system assessment (e.g. life cycle climate change impact, ecosystem function, and resilience).

The challenge is to develop a scheme that is sufficiently flexible to accommodate different geographical locations, production systems, social settings and monitoring capacity and which is also sufficiently robust and comprehensive to ensure objectives are met.

\section{Sustainability certification for biochar}

The development of a sustainability framework for biochar, employing the approaches described above, will facilitate acceptance of biochar by society and individual consumers. Options for implementation of a sustainability framework vary from good practice guidelines, through voluntary certification, to regulation. A scheme that involves assessment by an independent third party has greater credibility than self-declaration. A sustainability scheme could be supported by regulation that specifies requirements

Table 1. Sustainability schemes for bioenergy of relevance to biochar.

\begin{tabular}{|c|c|c|}
\hline Scheme & Reference & Comment \\
\hline $\begin{array}{l}\text { Global Bioenergy Partnership } \\
\text { (GBEP) }\end{array}$ & $\begin{array}{l}\text { GBEP Task Force on Sustainability (Global } \\
\text { Bioenergy Partnership, 2008) Inventory of } \\
\text { Current Initiatives on Sustainable Bioenergy } \\
\text { Development }\end{array}$ & $\begin{array}{l}\text { GBEP has developed } 24 \text { indicators covering environmental, social and } \\
\text { economic impacts of bioenergy, for national-level reporting. The next } \\
\text { phase (2012) will involve capacity-building and testing of indicators. }\end{array}$ \\
\hline $\begin{array}{l}\text { Round Table on Sustainable } \\
\text { Biofuels (RSB) }\end{array}$ & $\begin{array}{l}\text { (École Polytechnique Fédérale de } \\
\text { Lausanne, 2008) Global Principles and } \\
\text { Criteria for Sustainable Biofuels } \\
\text { Production : Version Zero }\end{array}$ & $\begin{array}{l}\text { Provides agreed principles and criteria for sustainable biofuel production, } \\
\text { developed from global stakeholder discussion intended as a basis for } \\
\text { certification. Version } 1 \text { is currently undergoing pilot testing in a number } \\
\text { of countries including a case study in Australia. }\end{array}$ \\
\hline $\begin{array}{l}\text { International Standards } \\
\text { Organization (ISO) ISO } 13065 \\
\text { Sustainability criteria for } \\
\text { bioenergy }\end{array}$ & $\begin{array}{l}\text { ISO Technical Committee } 248 \\
\text { (International Organization for } \\
\text { Standardization, 2012) }\end{array}$ & $\begin{array}{l}\text { Chaired by Germany and Brazil. Commenced in early 2010, due } \\
\text { for release in } 2014 \text {. Will develop sustainability indicators to assess } \\
\text { environmental, social and economic impacts of bioenergy for application } \\
\text { by industry }\end{array}$ \\
\hline $\begin{array}{l}\text { Bioenergy and Food Security } \\
\text { Criteria and Indicators } \\
\text { (BEFSCI) }\end{array}$ & $\begin{array}{l}\text { Food and Agriculture Organization of the } \\
\text { United Nations (2012) }\end{array}$ & $\begin{array}{l}\text { Aims to develop criteria and indicators reflecting the four dimensions } \\
\text { of food security (production, access, nutritional function and stability). } \\
\text { Intended to inform other initiatives (RSB, GBEP), as well as reporting } \\
\text { process on food security under the EU Renewable Energy Directive, } \\
\text { CEN and ISO. }\end{array}$ \\
\hline
\end{tabular}

Pesq. agropec. bras., Brasília, v.47, n.5, p.637-648, maio 2012 
for certification to access particular markets; biochar producers and users will be motivated to develop appropriate management systems and obtain certification to enable them to access these markets. Two examples of this approach include: the European Renewable Energy Directive (2009/28/EC) (European Parliament, 2009), under which, in order to count towards the renewable target, producers of biofuels must avoid certain feedstock sources (e.g., peatland cleared since January 2008), and feedstocks such as wastes are favored; and the Biofuels Act (2007) in the Australian state of New South Wales, which requires biofuel producers to meet sustainability requirements (currently specified as the RSB scheme), in order to qualify as eligible under the mandated biofuel target. This type of approach is particularly relevant for products traded internationally, as a mechanism by which importing countries can influence the production processes.

Establishment of a certification scheme will take time, to agree on intent, substance, and to develop the necessary institutional support and governance structures, including verification processes. Multiple schemes may emerge, requiring producers and consumers to choose between them. For example, this is the experience of the forestry sector, where multiple sustainability certification schemes now operate across the globe including the Forest Stewardship Council (FSC) and the Programme for the Endorsement of Forest Certification schemes (PEFC) (see below).

To support a certification scheme, methods for assessing biochar are required to identify whether biochars have undesirable properties or have been produced in environmentally unsound manner. Recent research into methods for characterizing key properties of biochar (Singh et al., 2010; Cross \& Sohi, 2011) could support such assessments. The International Biochar Initiative is working to produce guidelines for sustainable application of biochar to soil (International Biochar Initiative, 2012).

Recognizing that sustainability should consider the whole product life cycle, certification must assess all stages from feedstock production or procurement through processing to utilization. Assembling this information is relatively easy for a vertically-integrated business, but will be particularly challenging where biomass is obtained from multiple small-holders. The biochar producer will need to monitor and report on the systems of feedstock production and biochar processing, which will require resources that may be beyond the capacity of small producers. Thus certification schemes will favor larger producers, who have the capacity to invest, which could result in the displacement of small producers who are unable to access the restricted markets.

It has been suggested that sustainability certification could be employed as a barrier to trade (Junginger et al., 2010). Feeding this perception is the variable application and regulation of schemes across and between nations. Adequate governance to ensure that stated objectives of the respective schemes are addressed may be absent. As has been the experience for timber production, certification may be taken up largely by operators, and in those counties, for which there is less concern, with limited uptake in jurisdictions with weak or ineffective regulatory environment. These issues reduce credibility and acceptance of the value of certification schemes.

In some jurisdictions, all aspects of the biochar lifecycle are already regulated by various disconnected but overlapping schemes. For example, feedstock harvesting may come under one or more of the schemes outlined in Table 1; the construction and operation of a processing plant will come under local planning and environmental regulations; and the application of soil amendments may also be regulated by environment protection authorities. The biochar system may also be measured, monitored and verified to meet mandated or voluntary greenhouse gas emissions targets. Where existing systems for monitoring and reporting on sustainability are considered adequate, these systems could be recognized as meeting the requirements for sustainable biochar certification, in much the same way as the EU Renewable Energy Directive accepts biofuels certified under a range of certification schemes. Such a process for mutual recognition of existing and developing sustainability certification schemes would minimize unnecessary burden on participants and encourage adoption.

\section{Sustainability certification experiences in the forestry industry}

In developing robust systems for biochar, there is value in reviewing the experiences of the forestry industry in implementing certification for sustainable forest management. There are many studies which assess the efficacy of forest certification as a mechanism for facilitating sustainable forestmanagement (Karmann \& Smith, 2009; Peña-Claros et al., 2009). Karmann 
\& Smith (2009) reviewed the outcomes and impacts of FSC certification, drawing on a range of previous studies. They acknowledged the lack of systematic research design in evaluating 180 papers, but concluded that there was reliable evidence that FSC certification has improved the conservation status and enhanced biodiversity levels in certified forests. The certification process can catalyze changes to forest management even among industry leaders; the encouragement of a more participatory forest policy and process is one benefit (Ros-Tonen, 2004). Benefits to local communities and forest workers include employment of local people, and improvement of health and safety standards because FSC forest management standards are generally above those demanded by national legislation and regulations (Karmann \& Smith, 2009).

While there is continuing discussion over the efficacy of certification per se (FSC-watch (2012)), the bigger issue is that only a small proportion of the world's forests are certified, and that most of the certified forests are in countries where there are already regulatory and other mechanisms to promote sustainable forest management (Stupak et al., 2011). In 2007, certified forests covered 306.3 million ha, constituting about $7.9 \%$ of the 3.9 billion ha of global forests (Purbawiyatna \& Simula, 2008). More than $84 \%$ of the certified forests were in North America and Europe, and 7\% in developing countries (Purbawiyatna \& Simula, 2008).

In summary, although debate over the relative merit of each forestry certification scheme continues, it appears that in those countries that undertake international sustainability reporting [Montreal (Montréal Process Working Group, 2012) or Helsinki (International Institute for Sustainable Development, 2012) process] and have adequate governance to ensure compliance, or where robust certification schemes such as FSC are applied, there is evidence that there are improved sustainability outcomes. Where there is no reporting obligation, or absence of mechanisms to ensure measurement, monitoring or compliance, the reverse is true.

\section{Final considerations}

Biochar shows great promise as a technology that can contribute significantly to mitigation of climate change, whilst assisting in the reduction of land degradation and promoting agricultural productivity. Potential negative impacts of biochar systems can be addressed through adoption of best management practices in land use, for the provision of biomass and biochar application, and the utilization of advanced biochar production technologies to minimize pollution and optimize energy efficiency. Proactive development of robust industry guidelines and policies is needed to encourage adoption of these practices, to ensure that concerns of negative consequences are adequately addressed and do not divert attention from the multiple environmental benefits of biochar. These guidelines should promote adaptive and continuous improvement. Sustainable land use policies combined with effective regulation of biochar production facilities, incentives for efficient utilization of energy, and improved knowledge of biochar impacts on ecosystem health and productivity could provide a strong framework for development of a sustainable biochar industry. Sustainability certification could be introduced to provide confidence to consumers that sustainable practices have been employed along the production chain, particularly where biochar is traded internationally.

\section{Acknowledgements}

To IEA Bioenergy Task 38 and the Australian Department of Agriculture, Forestry and Fisheries provided funding to members of this research collaboration.

\section{References}

BIOFUELWATCH. Biochar: a critical review of science and policy. 2011. 42p. Available at: <http://www.see.ed.ac.uk/ shs/ Climate\%20change/Carbon\%20sequestration/Biochar\%20policy. pdf $>$. Accessed on: 23 May 2012.

BRIDLE, T.R.; PRITCHARD, D. Energy and nutrient recovery from sewage sludge via pyrolysis. Water Science and Technology, V.50, p.169-175, 2004.

BRINTON JUNIOR, W.F. Characterization of man-made foreign matter and its presence in multiple size fractions from mixed waste composting. Compost Science and Utilization, v.13, p.274-280, 2005.

BROWN, R. Biochar production technology. In: LEHMANN, J.; JOSEPH, S. (Ed.). Biochar for environmental management: science and technology. London: Earthscan, 2009. 127-139.

BUSHNAF, K.M.; PURICELLI, S.; SAPONARO, S.; WERNER, D. Effect of biochar on the fate of volatile petroleum hydrocarbons in an aerobic sandy soil. Journal of Contaminant Hydrology, v.126, p.208-215, 2011. 
CHEN, B.; YUAN, M. Enhanced sorption of polycyclic aromatic hydrocarbons by soil amended with biochar. Journal of Soils and Sediments, v.11, p.62-71, 2011.

CHERUBINI, F. GHG balances of bioenergy systems - overview of key steps in the production chain and methodological concerns. Renewable Energy, v.35, p.1565-1573, 2010.

CHERUBINI, F.; BIRD, N.; COWIE, A.; JUNGMEIER, G.; SCHLAMADINGER, B.; WOESS-GALLASCH, S. Energy- and greenhouse gas-based LCA of biofuel and bioenergy systems: key issues, ranges and recommendations. Resources, Conservation and Recycling, v.53, p.434-447, 2009.

COWIE, A.L.; SMITH, P.; JOHNSON, D. Does soil carbon loss in biomass production systems negate the greenhouse benefits of bioenergy? Mitigation and Adaptation Strategies for Global Change, v.11, p.979-1002, 2006.

CROSS, A.; SOHI, S.P. The priming potential of biochar products in relation to labile carbon contents and soil organic matter status. Soil Biology and Biochemistry, v.43, p.2127-2134, 2011.

CUYPERS, F.; HELSEN, L. Pyrolysis of chromated copper arsenate (CCA) treated wood waste at elevated pressure: influence of particle size, heating rate, residence time, temperature and pressure. Journal of Analytical and Applied Pyrolysis, v.92, p.111-122, 2011.

DELUCCHI, M.A. Impacts of biofuels on climate change, water use, and land use. Annals of the New York Academy of Sciences, v.1195, p.28-45, 2010.

DOWNIE, A.; MUNROE, P.; COWIE, A.; VAN ZWIETEN, L.; LAU, D.M.S. Biochar as a geo-engineering climate solution: hazard identification and risk management. Critical Reviews in Environmental Science and Technology, v.42, p.225-250, 2012.

DUKU, M.H.; GU, S.; HAGAN, E.B. Biochar production potential in Ghana: a review. Renewable and Sustainable Energy Reviews, v.15, p.3539-3551, 2011.

EUROPEAN PARLIAMENT. Directive 2009/28/EC of the European Parliament and of the Council of 23 April 2009 on the promotion of the use of energy from renewable sources and amending and subsequently repealing Directives 2001/77/EC and 2003/30/E. Official Journal of the European Union, v.140, L 140/1-L 140/61, 2009.

FARINE, D.R.; O'CONNELL, D.A.; RAISON, R.J.; MAY, B.M.; O'CONNOR, M.H.; CRAWFORD, D.F.; HERR, A.; TAYLOR, J.A.; JOVANOVIC, T.; CAMPBELL, P.K.; DUNLOP, M.I.A.; RODRIGUEZ, L.C.; POOLE, M.L.; BRAID, A.L.; KRITICOS, D. An assessment of biomass for bioelectricity and biofuel, and for greenhouse gas emission reduction in Australia. Global Change Biology Bioenergy, v.4, p.148-175, 2011.

ÉCOLE POLYTECHNIQUE FÉDÉRALE DE LAUSANNE. The Roundtable on Sustainable Biofuels. 2008. Available at: $<$ http:// rsb.epfl.ch/>. Accessed on: 30 May 2012.

FEHRENBACH, H.; GIEGRICH, J.; REINHARDT, G.; SCHMITZ, J.; SAYER, U.; GRETZ, M.; SEIZINGER, E.; LANJE, $\mathrm{K}$. Criteria for a sustainable use of bioenergy on a global scale. Dessau-Roßlau: Federal Environment Agency, 2008. 245p.
FELLET, G.; MARCHIOL, L.; DELLE VEDOVE, G.; PERESSOTTI, A. Application of biochar on mine tailings: effects and perspectives for land reclamation. Chemosphere, v.83, p.1262-1267, 2011.

FOOD AND AGRICULTURE ORGANIZATION OF THE UNITED NATIONS. Bioenergy and Food Security Criteria and Indicators (BEFSCI) project. Available at: $<$ http://www.fao.org/ bioenergy/foodsecurity/befsci/en/>. Accessed on: 28 may 2012.

FORSTER, P.; RAMASWAMY, V.; ARTAXO, P.; BERNTSEN, T.; BETTS, R.; FAHEY, D.W.; HAYWOOD, J.; LEAN, J.; LOWE, D.C.; MYHRE, G.; NGANGA, J.; PRINN, R.; RAGA, G.; SCHULZ, M.; VAN DORLAND, R. Changes in atmospheric constituents and in radiative forcing. In: SOLOMON, S.; QIN, D.; MANNING, M.; CHEN, Z.; MARQUIS, M.; AVERYT, K.B.; TIGNOR, M.; MILLER, H.L. (Ed.). Climate Change 2007: the physical science basis: contribution of Working Group I to the Fourth Assessment Report of the Intergovernmental Panel on Climate Change. Cambridge: Cambridge University, 2007. p.129-234.

FSC-WATCH. FSC-WATCH [home page]. Available at: <http:// www.fsc-watch.org/>. Accessed on: 28 may 2012.

GAUNT, J.; COWIE, A. Biochar, greenhouse gas accounting and emissions trading. In: LEHMANN, J.; JOSEPH, S. (Ed.). Biochar for environmental management: science and technology. London: Earthscan, 2009. p.317-340.

GLOBAL BIOENERGY PARTNERSHIP. GBEP task force on sustainability. Available at: <http://www.globalbioenergy.org/>. Accessed on: 30 May 2012.

GOMEZ-EYLES, J.L.; SIZMUR, T.; COLLINS, C.D.; HODSON, M.E. Effects of biochar and the earthworm Eisenia fetida on the bioavailability of polycyclic aromatic hydrocarbons and potentially toxic elements. Environmental Pollution, v.159, p.616-622, 2011.

HAMMOND, J.; SHACKLEY, S.; SOHI, S.; BROWNSORT, P. Prospective life cycle carbon abatement for pyrolysis biochar systems in the UK. Energy Policy, v.39, p.2646-2655, 2011.

INTERNATIONAL BIOCHAR INITIATIVE. International Biochar Initiative [home page]. Available at: <http://www. biochar-international.org/>. Accessed on: 28 may 2012.

INTERNATIONAL INSTITUTE FOR SUSTAINABLE DEVELOPMENT. The Helsinki process. Available at: $<$ http:// www.iisd.ca/forestry/hel.html>. Accessed on: 28 May 2012.

INTERNATIONAL ORGANIZATION FOR STANDARDIZATION. ISO 14040:2006: environmental management - life cycle assessment - principles and framework. Switzerland: International Organization for Standardization, 2006. 28p.

INTERNATIONAL ORGANIZATION FOR STANDARDIZATION. TC 248: sustainability criteria for bioenergy. Available at: <http://www.iso.org/iso/iso_technical_ committee?commid=598379>. Accessed on: 28 May 2012.

JANOWIAK, M.K.; WEBSTER, C.R. Promoting ecological sustainability in woody biomass harvesting. Journal of Forestry, v.108, p.16-23, 2010. 
JEFFERY, S.; VERHEIJEN, F.G.A.; VAN DER VELDE, M.; BASTOS, A.C. A quantitative review of the effects of biochar application to soils on crop productivity using meta-analysis. Agriculture, Ecosystems and Environment, v.144, p.175-187, 2011.

JUNGINGER, M.; DAM, J. van; ZARRILLI, S.; MOHAMED, F.A.; MARCHAL, D.; FAAIJ, A. Opportunities and barriers for international bioenergy trade. Utrecht: Copernicus Institute: Utrecht University, 2010. 76p.

KAKITANI, T.; HATA, T.; KAJIMOTO, T.; IMAMURA, Y. Two possible pathways for the release of arsenic during pyrolysis of chromated copper arsenate (CCA)-treated wood. Journal of Hazardous Materials, v.113, p.247-252, 2004.

KAMMANN, C.; LINSEL, S.; GÖßLING, J.; KOYRO, H.-W. Influence of biochar on drought tolerance of Chenopodium quinoa Willd and on soil-plant relations. Plant and Soil, v.345, p.195-210, 2011.

KARHU, K.; MATTILA, T.; BERGSTROM, I.; REGINA, K. Biochar addition to agricultural soil increased $\mathrm{CH} 4$ uptake and water holding capacity - results from a short-term pilot field study. Agriculture, Ecosystems and Environment, v.140, p.309-313, 2011.

KARMANN, M.; SMITH, A. FSC reflected in scientific and professional literature: literature study on the outcomes and impacts of FSC certification. [S.1.]: Forest Stewardship Council, 2009. 244p.

KEITH, A.; SINGH, B.; SINGH, B.P. Interactive priming of biochar and labile organic matter mineralization in a smectite-rich soil. Environmental Science and Technology, v.45, p.9611-9618, 2011.

KINNEY, T.J.; MASIELLO, C.A.; DUGAN, B.; HOCKADAY, W.C.;DEAN,M.R.;ZYGOURAKIS, K.;BARNES, R.T.Hydrologic properties of biochars produced at different temperatures. Biomass and Bioenergy, v41, p.34-43, 2012.

KOOKANA, R.S.; SARMAH, A.K.; VAN ZWIETEN, L.; KRULL, E.; SINGH, B. Chapter three - biochar application to soil: agronomic and environmental benefits and unintended consequences. Advances in Agronomy, v.112, p.103-143, 2011.

LEHMANN, J.; GAUNT, J.; RONDON, M. Bio-char sequestration in terrestrial ecosystems: a review. Mitigation and Adaptation Strategies for Global Change, v.11, p.403-427, 2006.

LEHMANN, J.; JOSEPH, S. Biochar for environmental management: science and technology. London: Earthscan, 2009. $416 \mathrm{p}$.

LEWANDOWSKI, I.; FAAIJ, A.P.C. Steps towards the development of a certification system for sustainable bio-energy trade. Biomass and Bioenergy, v.30, p.83-104, 2006.

LIANG, B.; LEHMANN, J.; SOHI, S.P.; THIES, J.E.; O’NEILL, B.; TRUJILLO, L.; GAUNT, J.; SOLOMON, D.; GROSSMAN, J.; NEVES, E.G.; LUIZÃO, F.J. Black carbon affects the cycling of non-black carbon in soil. Organic Geochemistry, v.41, p.206-213, 2010 .

LUO,Y.; DURENKAMP, M.; DENOBILI, M.; LIN, Q.; BROOKES, P.C. Short term soil priming effects and the mineralisation of biochar following its incorporation to soils of different $\mathrm{pH}$. Soil Biology and Biochemistry, v.43, p.2304-2314, 2011.

MONTRÉAL PROCESS WORKING GROUP. The Montreal Process. Available at: <http://www.rinya.maff.go.jp/mpci/>. Accessed on: 28 May 2012.

NAMGAY, T.; SINGH, B.; SINGH, B.P. Influence of biochar application to soil on the availability of $\mathrm{As}, \mathrm{Cd}, \mathrm{Cu}, \mathrm{Pb}$, and $\mathrm{Zn}$ to maize (Zea mays L.). Australian Journal of Soil Research, v.48, p.638-647, 2010 .

O'CONNELL, D.; BRAID, A.; RAISON, J.; HANDBERG, K.; COWIE, A.; RODRIGUEZ, L.; GEORGE, B. Sustainable production of bioenergy: a review of global bioenergy sustainability frameworks and assessment system. Canberra: Rural Industries Research and Development Corporation, 2009. 164p.

PARK, J.H.; CHOPPALA, G.K.; BOLAN, N.S.; CHUNG, J.W.; CHUASAVATHI, T. Biochar reduces the bioavailability and phytotoxicity of heavy metals. Plant and Soil, v.348, p.439-451, 2011.

PEÑA-CLAROS, M.; BLOMMERDE, S.; BONGERS, F. Assessing the progress made: an evaluation of forest management certification in the tropics. Wageningen: Wageningen University, 2009. 76p. (Tropical resource management papers, 95).

PENG, X.; YE, L.L.; WANG, C.H.; ZHOU, H.; SUN, B. Temperature- and duration-dependent rice straw-derived biochar: characteristics and its effects on soil properties of an Ultisol in southern China. Soil and Tillage Research, v.112, p.159-166, 2011.

PURBAWIYATNA, A.; SIMULA, M. Developing forest certification: towards increasing the comparability ad acceptance of forest certification systems. Yokohama: International Tropical Timber Orgazination, 2008. 126p. (ITTO. Technical series, 29).

ROBERTS, K.G.; GLOY, B.A.; JOSEPH, S.; SCOTT, N.R.; LEHMANN, J. Life cycle assessment of biochar systems: estimating the energetic, economic, and climate change potential. Environmental Science and Technology, v.44, p.827-833, 2010.

ROS-TONEN, M.A.F. The final report of the congress on 'Globalisation, localisation and tropical forest management in the 21st century', held in Amsterdam on 22-23 October 2003. Amsterdam: University of Amsterdam, 2004. 40p.

SINGH, B.P.; COWIE, A. The mean turnover time of biochar in soil varies depending on biomass source and pyrolysis temperature. In: WORLD CONGRESS OF SOIL SCIENCE, SOIL SOLUTIONS FOR A CHANGING WORLD, 19., 2010, Brisbane. Proceedings. Brisbane: IUSS, 2010. p.235-238.

SINGH, B.P.; HATTON, B.J.; SINGH, B.; COWIE, A.L.; KATHURIA, A. Influence of biochars on nitrous oxide emission and nitrogen leaching from two contrasting soils. Journal of Environmental Quality, v.39, p.1224-1235, 2010.

STANDARDS AUSTRALIA. AS 4454: composts, soil conditioners and mulches. Sydney: Standards Australia International, 2003. $55 \mathrm{p}$.

STREUBEL, J.D.; COLLINS, H.P.; GARCIA-PEREZ, M.; TARARA, J.; GRANATSTEIN, D.; KRUGER, C.E. Influence of contrasting biochar types on five soils at increasing rates of 
application. Soil Science Society of America Journal, v.75, p.1402-1413, 2011.

STUPAK, I.; LATTIMORE, B.; TITUS, B.D.; TATTERSALL SMITH, C. Criteria and indicators for sustainable forest fuel production and harvesting: a review of current standards for sustainable forest management. Biomass and Bioenergy, v.35, p.3287-3308, 2011.

SUN, K.; KEILUWEIT, M.; KLEBER, M.; PAN, Z.; XING, B. Sorption of fluorinated herbicides to plant biomass-derived biochars as a function of molecular structure. Bioresource Technology, v.102, p.9897-9897-9903, 2011.

UCHIMIYA, M.; BANNON, D.I.; WARTELLE, L.H. Retention of heavy metals by carboxyl functional groups of biochars in small arms range soil. Journal of Agricultural and Food Chemistry, v.60, p.1798-1809, 2012.

URABE, T.; IMASAKA, T. Analysis of thermal decomposition products arising from polyvinyl chloride analogs by supersonic jet/multiphoton ionization/mass spectrometry. Talanta, v.52, p.703-709, 2000.

VAN DAM, J.; JUNGINGER, M.; FAAIJ, A.; JÜRGENS, I.; BEST, G.; FRITSCHE, U. Overview of recent developments in sustainable biomass certification. Biomass and Bioenergy, v.32, p.749-780, 2008.

VAN ZWIETEN, L.; KIMBER, S.; MORRIS, S.; CHAN, K.; DOWNIE, A.; RUST, J.; JOSEPH, S.; COWIE, A. Effects of biochar from slow pyrolysis of papermill waste on agronomic performance and soil fertility. Plant and Soil, v.327, p.235-246, 2010a.

VAN ZWIETEN, L.; KIMBER, S.; MORRIS, S.; DOWNIE, A.; BERGER, E.; RUST, J.; SCHEER, C. Influence of biochars on flux of $\mathrm{N} 2 \mathrm{O}$ and $\mathrm{CO} 2$ from Ferrosol. Australian Journal of Soil Research, v.48, p.555-568, 2010b.

VERHEIJEN, F.; JEFFERY, S.L.; BASTOS, A.C.; VAN DER VELDE, M.; DIAFAS, I. Biochar application to soils: a critical scientific review of effects on soil properties, processes and functions. Luxembourg: European Commission, 2010. 162p.

WARDLE, D.A.; NILSSON, M.-C.; ZACKRISSON, O. Fire-derived charcoal causes loss of forest humus. Science, v.320, p.629, 2008. (RESUMO).

WATERS, D.; VAN ZWIETEN, L.; SINGH, BHUPINDER-PAL; DOWNIE, A.L.; COWIE, A.L.; LEHMANN, J.. Biochar in soil for climate change mitigation and adaptation. Soil Health and Climate Change, v.29, p.345-368, 2011.

WERHAHN-MEES, W.; PALOSUO, T.; GARCIA-GONZALO, J.; ROSER, D.; LINDNER, M. Sustainability impact assessment of increasing resource use intensity in forest bioenergy production chains. Global Change Biology Bioenergy, v.3, p.91-106, 2011.

WIJESEKARA, R.G.S.; NAVARRO, R.R.; MATSUMURA, M. Removal and recovery of mercury from used fluorescent lamp glass by pyrolysis. Journal of the National Science Foundation of Sri Lanka, v.39, p.235-241, 2011.

WOOLF, D.; AMONETTE, J.E.; STREET-PERROTT, F.A.; LEHMANN, J.; JOSEPH, S. Sustainable biochar to mitigate global climate change. Nature Communications, v.1, p.56, 2010.

WU, H.; FU, Q.; GILES, R.; BARTLE, J. Production of mallee biomass in Western Australia: energy balance analysis. Energy and Fuels, v.22, p.190-198, 2008.

Received on January 3, 2012 and accepted on April 30, 2012

Pesq. agropec. bras., Brasília, v.47, n.5, p.637-648, maio 2012 